\title{
logopaedica
ogziensia
}

$\mathrm{Nr} 3$ (2019)

D0l: http://dx.doi.org/10.18778/2544-7238.03.02

Ewa Bielenda-Mazur* (iD, Anna Siudak** (iD)

\section{Gest wskazywania palcem w świetle doniesień neurobiologicznych}

Pointing gesture in neurobiological reports

Słowa kluczowe: gest wskazywania palcem, naprzemienność ról, rewolucja dziewiątego miesiąca, rozwój dziecka

Keywords: pointing gesture, exchange of roles, revolution of the ninth month, child development

\section{Ewolucyjne znaczenie gestu wskazywania palcem}

Zgodnie z gestową teorią powstania języka ${ }^{1}$ ewolucyjnym substratem języka były gesty manualne, za pomocą których porozumiewał się człowiek [za: Kurcz, Tomaszewski, 2011]. Początkowo były to gesty ikoniczne (znaki podobne do desygnatu), jednak wraz z powiększającą się pojemnością ludzkiej pamięci zaczęły one stawać się coraz bardziej arbitralne, a przez to także efektywne i odnoszące się do większej liczby desygnatów [Kurcz, 1992]. Z dużym prawdopodobieństwem na etapie przejściowym, wraz z nowymi możliwościami artykulacyjnymi człowieka, pojawiła się ikoniczna synchronizacja gestów manualnych z gestami wokalnymi (wokalizacjami) [Kurcz, Tomaszewski, 2011]. Mają one wspólną ścieżkę ewolucyjną, ponieważ zarówno ruchy narządów artykulacyjnych, jak i gesty manualne zawiadywane są przez mięśnie szkieletowe. O ile gesty manualne umożliwiały porozumiewanie się w sytuacjach, gdy partnerzy komunikacji nie chcieli zwracać na siebie uwagi (np. podczas

\footnotetext{
* Uniwersytet Pedagogiczny w Krakowie, Katedra Logopedii i Zaburzeń Rozwoju, ul. Podchorążych 2, 30-084 Kraków, e-mail: ewa.bielenda-mazur@up.krakow.pl, https://orcid.org/0000-0001-6206-7516 ** Uniwersytet Pedagogiczny w Krakowie, Katedra Logopedii i Zaburzeń Rozwoju, ul. Podchorążych 2, 30-084 Kraków, e-mail: anna.siudak@up.krakow.pl, https://orcid.org/0000-0002-1986-9078 1 Gestowa teoria powstawania języka zakłada, że przodkowie współczesnego człowieka byli w stanie komunikować się intencjonalnie za pomocą gestów, nie byli natomiast zdolni do zapanowania nad swoimi wokalizacjami. Dopiero gdy posiedli tę zdolność, gesty zostały stopniowo wyparte przez język mówiony.
} 
polowania), o tyle gesty wokalne sprawiły, że wymiana informacji dostępna była w sytuacjach utrudniających kontakt wzrokowy (np. w ciemności).

Mimo że we współczesnej komunikacji dominuje porozumiewanie się oparte na mowie wokalnej, gesty - zarówno wokalne, jak i manualne - nadal odgrywają znaczącą rolę. Zgodnie z motoryczną teorią percepcji mowy Alvina Libermana ${ }^{2}$ percypujemy nie tylko dźwięki, ale też artykulacyjne gesty mówiącego. Potwierdzają to również badania nad rolą neuronów lustrzanych w produkcji i percepcji mowy - podczas słuchania mowy aktywują się mięśnie pobudzane w trakcie jej produkowania ${ }^{3}$ [za: Kurcz, 2011].

Ponieważ zainteresowanie elementami niewerbalnej komunikacji sięga w naszej kulturze czasów antycznych, powstało wiele prób ich systematyzacji. Jedną z najistotniejszych dla potrzeb językoznawstwa jest typologia gestów Davida McNeilla, który wyróżnia [za: Załazińska, 2006]:

1) gesty deiktyczne, tzw. deiksy - wskazujące konkretną rzecz lub elementy istniejące w abstrakcyjnej przestrzeni mentalnej osoby mówiącej;

2) uderzenia (beats) - zwane w innych podziałach batutami; są to intonacyjne, rytmiczne gesty związane $\mathrm{z}$ tokiem wypowiadanych słów, podkreślające ich ważność, polegające na ruchach ręki w przestrzeni przed sobą;

3) gesty kohezywne (spajacze tekstu) - gesty łączące bliskie tematycznie elementy dyskursu, oddzielone czasowo od siebie w toku wypowiedzi;

4) gesty ikoniczne - gesty ujawniające bezpośrednie podobieństwo w swojej formie do struktury pojęciowej;

5) gesty metaforyczne - znaki procesów myślowych.

Najistotniejszym w rozwoju człowieka gestem jest deiktyczny gest wskazywania palcem. Żeby mógł on zaistnieć, dziecko musi przejść określoną drogę rozwoju motorycznego, poznawczego i społecznego.

\section{Motoryczne uwarunkowania gestu wskazywania palcem}

Wyodrębnienie palca wskazującego spośród pozostałych palców dłoni warunkowane jest przez odpowiednie bodźcowanie. Dzięki stymulacji możliwe jest prawidłowe rozwijanie się w korze mózgowej reprezentacji czuciowo-ruchowej dłoni,

2 Zgodnie z tą teorią, słysząc mowę, interpretujemy odbierane sygnały przez odniesienie się do motoryki artykulacyjnych gestów mówiącego. Wykorzystujemy wówczas inne procesy słuchowe niż na przykład podczas słuchania muzyki - odwołujące się do naszej wiedzy o wzorcach artykulacyjnych. Percepcja mowy właściwa jest wyłącznie gatunkowi ludzkiemu.

3 Dowodzi tego między innymi tzw. efekt McGurka. Wiele badań dzieci niewidzących wskazuje, iż wolniej rozwijają one mowę. Są też liczne analizy, które temu zaprzeczają - przeglądu badań dotyczących specyfiki rozwoju mowy (z uwzględnieniem poszczególnych podsystemów języka) dzieci z uszkodzeniami narządu wzroku dokonali Katarzyna Kaczorowska-Bray i Stanisław Milewski [2016]. 
ze szczególnym uwzględnieniem palców. Nadreprezentacja korowa dłoni (oraz twarzy, szczególnie ust), pozwalająca na dokładną kontrolę ruchów dłoni (i twarzoczaszki), umożliwia posługiwanie się ręką jako „[...] precyzyjnym narzędziem, dzięki któremu człowiek może oddziaływać na środowisko" [Zyss, 2011, s. 35-47]. Dojrzewanie homunkulusa ruchowego, „ludzika” o nieproporcjonalnie wielkiej głowie i wielkich rękach odzwierciedlających symbolicznie mapę somatotopową ciała ludzkiego (ruchowo-czuciową reprezentację kory mózgowej), przebiega według ściśle określonego porządku, który dyktowany jest przez rozwój sprawności motorycznych i manualnych [Zyss, 2011].

U zdrowego czuwającego noworodka dłoń jest częścią całości zgięciowego ułożenia ciała, dlatego ręka pozostaje przeważnie zamknięta, tj. kciuk jest przywiedziony w dłoni, a pozostałe palce zgięte. Rozwój motoryki ręki rozpoczyna prymitywny odruch chwytny, tj. szybkie i odruchowe zamykanie dłoni noworodka pod wpływem bodźca oraz następującego po nim tonicznego silnego trzymania. W czasie pierwszego i drugiego miesiąca życia podczas czuwania dziecka całościowe ułożenie zgięciowe gwałtownie maleje i dłonie coraz częściej pozostają lekko otwarte. Pod koniec trzeciego miesiąca, wskutek centralizacji napięcia mięśniowego, tułów staje się stabilny i kończyny mogą poruszać się w miarę swobodnie (do tej pory poruszały się tylko po bokach ciała). Dzięki temu ramiona mogą przemieścić się w kierunku przyśrodkowym, a dziecko ma możliwość obserwacji własnych rączek lub wyciągnięcia dłoni w kierunku atrakcyjnego przedmiotu (w czwartym miesiącu dłonie pozostają najczęściej półotwarte). Osiągnięcie linii środkowej umożliwia także dotknięcie się obu rąk na linii wzroku, co rozpoczyna prymitywną manipulację (dziecko w tym okresie zaczyna bawić się swoimi rączkami) oraz zwiastuje rozwój koordynacji „oko - ręka”, która w piątym miesiącu życia przybiera formę kierunkowego prostowania ramion w stronę zabawki [Hellbrugge i wsp., 2016, s. 134-135]. Doskonalenie tej umiejętności przynosi dziecku w szóstym miesiącu życia celny chwyt dłoniowy, tzn. że przedmioty bierze całą powierzchnią dłoni z wyprostowanym kciukiem (kciuk dotyka przedmiotu); ręka pozostaje w ułożeniu pronacyjnym (powierzchnia dłoni skierowana ku dołowi). W tym czasie pojawia się także umiejętność przekładania zabawki z jednej ręki do drugiej, co możliwe jest dzięki dwóm nowym, odmiennym dla każdej ręki funkcjom: świadomemu trzymaniu przedmiotu przez rękę biorącą (odruch chwytny powinien zaniknąć do końca szóstego miesiąca) oraz puszczaniu przedmiotu przez rękę podającą (czas rozluźniania palów nie powinien w tym wieku przekroczyć pięciu sekund). W kolejnych dwóch miesiącach życia następuje dalsze doskonalenie umiejętności chwytania, które zostaje wzbogacone o możliwość chwytania obiema rączkami, przy czym przedmiot zostaje w obu dłoniach jedynie przez kilka sekund. Oznacza to jednak, że niemowlę koncentruje swoją uwagę na dwóch dłoniach równocześnie. W tym samym czasie zmienia się także mechanika ręki i dziecko potrafi wziąć mniejsze przedmioty końcami palców (dystalnie), bez dotykania ich wnętrzem dłoni, tj. kilkoma zgiętymi palcami z wyprostowanym 
kciukiem. W literaturze przedmiotu nie ma zgodności co do dokładnego momentu wystąpienia tej umiejętności, najczęściej przyjmuje się jednak, że powinien to być siódmy, ósmy miesiąc życia. Pojawienie się tego etapu w rozwoju motorycznym warunkuje w sposób fundamentalny także rozwój poznawczy, ponieważ opozycja palec wskazujący - kciuk stanowi podstawę gestu wskazywania. Doskonalenie się pozycji dłoni z przeciwstawnym kciukiem umożliwia dziecku ćwiczenie nowego sposobu chwytania $-z$ wyprostowanym palcem wskazującym. Jest to tzw. chwyt pęsetowy, który powinien pojawić się w rozwoju pod koniec dziesiątego miesiąca [Hellbrugge i wsp., 2016, s. 134-135].

Stopniowe dojrzewanie ruchu chwytnego u dziecka następuje od większych mięśni barków i ramion do coraz drobniejszych, tj. mięśni nadgarstka, kciuka i wreszcie palca wskazującego. Rozwój chwytu i pojawienie się gestu wskazywania są zatem determinowane przez umiejętności dużej motoryki. Szczególnie ważne w tym zakresie jest osiągnięcie podparcia na wyprostowanych przedramionach, na wpół lub całkowicie otwartych dłoniach pod koniec szóstego miesiąca. Dzięki kontaktowi otwartej dłoni z podłożem oraz przeniesieniu części ciężaru ciała na dłonie możliwe jest doznawanie wielu wrażeń taktylnych: dotyku, ucisku, bólu, wibracji, zmian termicznych, wrażeń kinestetycznych ${ }^{4}$. Dziecko układane na rozmaitych podłożach nie tylko odczuwa podobieństwa i różnice ciężaru, oporu, kształtu, twardości, elastyczności i temperatury, stymulując w ten sposób rozwój kory czuciowej, lecz także uczy się rozpoznawać doświadczenia swojego ciała w zróżnicowanym środowisku (czucie proprioceptywne) ${ }^{5}$. Rozluźnienie palców i otwarcie dłoni jest istotne także dla rozwoju motoryki ręki, ponieważ początkowo dziecko chwyta przedmioty, dotykając ich wewnętrzną powierzchnią od strony łokciowej, tj. czterema palcami, bez użycia kciuka, a dopiero wraz z usprawnianiem się zdolności manipulacyjnych odsuwa je w stronę czubków palców - szczególnie palca wskazującego [Hellbrugge i wsp., 2016, s. 131], co daje motoryczne podstawy do pojawienia się gestu wskazywania.

\section{Poznawcze uwarunkowania gestu wskazywania palcem}

Neurobiologiczne podłoże gestów wskazuje jednak na to, iż nie są one jedynie działaniem motorycznym. Są również, a może przede wszystkim, aktem komunikacyjnym. Udowodnił to choćby przypadek pacjenta $\mathrm{z}$ apraksją, określanego w literaturze jako $I W$, który bez kontroli wzrokowej nie mógł celowo poruszać palcami rąk, a był zdolny gestykulować [Cole, Gallagher, McNeill, 2002]. Ponadto odnotowano przypadki, gdy uszkodzenia w okolicy ośrodków mowy Broki i Wernickego skutkowały

4 Klasyfikacja wrażeń taktylnych zob. Przezwański [1959].

5 Więcej o znaczeniu zmysłu dotyku zob. Siudak [2019]. 
również trudnościami w zakresie tworzenia i rozumienia gestykulacji [Iverson, Thelen, 1999]. Badania komunikacji osób niewidomych dowodzą, że niewidomi od urodzenia również gestykulują, nawet podczas komunikacji z osobą niewidzącą [por. Załazińska, 2006; Bauer, 2008]. Gesty nie powstają zatem jedynie po to, aby ułatwić interlokutorowi odbiór komunikatu [Goldin-Meadow, 1999].

Jak twierdzi Aneta Załazińska:

Gesty nie są zatem motorycznym suplementem mowy, ani nie są mowie podległe, ale semantycznie i pragmatycznie z nią skoordynowane. Oczywiście gest nie jest czysto lingwistycznym czy komunikacyjnym fenomenem. Wymaga on kontroli motorycznej i w ten sposób jest ucieleśniony w bardzo pierwotny sposób. Pomimo że gest, a także mowa (w znaczeniu artykulacji) pierwotnie uzależnione są od możliwości ruchowych ciała, jako warunku koniecznego, to jednak daleko przekraczają one sferę czystej motoryki i przenoszą nas do przestrzeni semantycznej języka, która jest także przestrzenią pragmatyczną komunikacji. Język nie jest zatem redukowalny ani do czysto motorycznych, ani do czysto ideacyjnych aspektów. Jest użyciem ciała w celach komunikacyjnych definiowalnych przez zasady pragmatyczne [Załazińska, 2006, s. 87].

W odniesieniu do przywołanych badań i obserwacji należy zauważyć, iż gesty pełnią zarówno rolę intrapersonalną (biorą udział w formułowaniu myśli - gestykulujemy również podczas monologu czy rozmowy telefonicznej), jak i interpersonalną (w procesie komunikacyjnym twarzą w twarz z rozmówcą używamy ich częściej). Podobnie jak słowa, są ściśle zależne od kontekstu - jeden gest może pełnić różne funkcje, również jednocześnie. Choć niektóre gesty stanowią ekwiwalenty słów, odmienna jest ich natura: ,język mówiony ma charakter linearno-analityczny, a gesty globalno-syntetyczny" [Załazińska, 2006, s. 91]. Ów odmienny charakter języka mówionego i gestowego ma istotne znaczenie dla rozumienia rozwoju komunikacji $\mathrm{w}$ okresie niemowlęcym i poniemowlęcym, kiedy to przetwarzanie informacji bazuje początkowo na mechanizmach prawej półkuli mózgu, której program działania można określić jako globalny (symultaniczny, holistyczny), stopniowo zaś dla funkcji językowych przewagę zdobywa program linearny (sekwencyjny), właściwy dla półkuli lewej [por. Springer, Deutsch, 2004]. Linia rozwoju komunikacji przebiega zatem od znaczących gestów po słowa.

Choć w omawianym kontekście przywołuje się najczęściej istotne zmiany, jakie przynosi tzw. rewolucja dziewiątego miesiąca, to nie sposób bagatelizować ujawniających się wcześniej zdolności mentalnych, które stanowią kanwę dla kształtowania się gestów - naprzemienności ról i pola wspólnej uwagi. Liczne prace na temat rozwoju mowy dowodzą, iż język ma swoje prenatalne źródła, począwszy od okresu noworodkowego, rozwija się intensywnie wraz z istotnymi dlań funkcjami poznawczymi i społecznymi [Bokus, Shugar, 2007; Jusczyk, 2007; Siudak, 2015; 2018; Korendo, Bielenda-Mazur, 2016; 2018]. Naprzemienność obserwować 
można w interakcji społecznej już u dziecka między drugim a trzecim miesiącem życia, kiedy to w kontakcie z opiekunem ujawnia się zamiana ról podczas wymiany komunikatów - zarówno werbalnych (ze strony opiekuna jest to najczęściej mowa matczyna, ze strony niemowlęcia repertuar zachowań werbalnych: wydawanych dźwięków samogłoskowych, spółgłoskopodobnych), jak i niewerbalnych (ekspresji taktylnej, mimicznej i motorycznej, ujawniającej się najczęściej w postaci ruchów kończyn) [zob. Tomasello, 2002; Białecka-Pikul, Stępień-Nycz, Karwala, 2014]. Colvyn Trevarthen nazwał te zachowania intersubiektywnością pierwotną, a intersubiektywnością wtórną określił działania ujawniające się pod koniec pierwszego roku życia, kiedy dziecko, posiadające już szereg doświadczeń związanych z eksploracją i manipulacją przedmiotami, zaczyna angażować się w działanie oparte na braniu i dawaniu [za: Białecka-Pikul, Stępień-Nycz, Karwala, 2014]. Zabawy w branie i dawanie są ściśle zależne od sprawności motorycznej, ale stanowią istotny trening społeczny i komunikacyjny, w którym dziecko odkrywa możliwość zmiany ról ze sprawcy na odbiorcę. Elementy naprzemienności ról pojawiają się bardzo wcześnie (nawet w pierwszych tygodniach życia), ponieważ wskutek dojrzewania neuronów lustrzanych dziecko wpada w tzw. rezonans neurobiologiczny, dzięki któremu możliwe jest naśladowanie działań drugiego człowieka czy też współodczuwanie jego stanów emocjonalnych [Bauer, 2008] ${ }^{6}$. Jednakże rozkwit tych umiejętności przypada na dziewiąty miesiąc życia niemowlęcia, co warunkowane jest przede wszystkim przez możliwość naśladowania działań dorosłego oraz pojawienie się pola wspólnej uwagi. Stanowiąca podstawę do kształtowania się pola wspólnej uwagi zdolność podążania za spojrzeniem pojawia się stosunkowo wcześnie - zaobserwowano ją już u dwumiesięcznych dzieci. W tej grupie wiekowej odnotowano jednak jedynie naśladowanie spojrzeń kierowanych w lewo i prawo w pustej przestrzeni [Scaife, Bruner, 1975]. Bardziej wyraziste wyniki dały natomiast badania ośmiomiesięcznych dzieci. George Butterworth i Nicholas Jarrett [1991], sprawdzając zdolność podążania za wzrokiem osoby dorosłej, przebadali dzieci w wieku 6-18 miesięcy i wykazali, że dopiero w szóstym miesiącu życia dzieci zwracają się w tym samym kierunku co dorosły, ale patrzą na przypadkowy obiekt z prezentowanej pary. W dwunastym miesiącu życia dziecko ekstrapoluje położenie przedmiotu na podstawie kierunku spojrzenia matki. W wieku poniemowlęcym dzieci radzą sobie z lokalizacją przedmiotu, na który patrzy matka,

6 Teoria neuronów lustrzanych zakłada istnienie komórek neuronalnych, które w filogenezie wpłynęły na rozwój mowy człowieka, a w ontogenezie warunkują uczenie i w rezultacie przystosowanie do zasad językowych oraz społecznych. Rozwój ten następuje przez naśladownictwo, a możliwy jest dzięki umiejscowieniu komórek nerwowych odpowiedzialnych za generowanie mowy w tych samych obszarach mózgu co neurony odpowiedzialne za ruchowe działania człowieka. Tezę tę potwierdzają badania nad rozwojem mowy dziecka, wykazujące równoległy rozwój motoryki oraz języka już u niemowląt. Według Joachima Bauera mowa, będąca częścią lustrzanego układu, umożliwia ludziom wzajemne zrozumienie się przez wywoływanie w umyśle lustrzanych odbić wyobrażeń działań osób biorących udział w interakcji [zob. Bauer, 2008, s. 58]. 
nawet gdy jest on poza ich polem widzenia, pod warunkiem, że nie ma innego „konkurencyjnego" przedmiotu.

W omawianym kontekście niezwykle istotne są spostrzeżenia Michaela Tomasello, który podkreśla rangę zmian, jakie zachodzą w umyśle dziecka od czasu, gdy skończy osiem miesięcy. Uznaje on, iż wówczas niemowlę zaczyna postrzegać innych jako istoty intencjonalne - „takie jak ja”, a czas rozpoczęcia owych zmian nazywa rewolucją dziewiątego miesiąca. Na mocy wspomnianej zdolności dziecko zaczyna posługiwać się narzędziami kulturowymi, spośród których najistotniejszy jest język. Wcześniej, w siódmym miesiącu życia, koncentruje się albo na manipulacji przedmiotem, albo na kontakcie z osobą, podczas gdy w dziewiątym miesiącu relacja staje się trójstronna: dziecko - obiekt (lub zdarzenie) - dorosły. Dzięki zaistnieniu pola wspólnej uwagi możliwe są: podążanie za wzrokiem (dziecko patrzy tam, gdzie patrzy dorosły), wspólne zaangażowanie (angażuje się w długie interakcje społeczne z udziałem obiektów), odniesienie społeczne (traktuje dorosłych jako społeczne punkty odniesienia) i uczenie się przez naśladownictwo. Dziecko zaczyna kierować uwagą lub zachowaniem osób dorosłych, wskazując palcem czy podnosząc w ich kierunku przedmioty. Pośród gestów wskazywania palcem zauważyć można zarówno nakazy, jak i oznajmienia [Tomasello, 2002].

Badania Rogera Bakemana i Lauren B. Adamson [1984] dowiodły, że wraz z wiekiem maleje liczba interakcji jedynie z opiekunem na rzecz wspólnego, koordynowanego zaangażowania zarówno z osobą, jak i przedmiotem. Największa dynamika zmiany w tym zakresie przypada na czas po dwunastym miesiącu życia [zob. Białecka-Pikul, Stępień-Nycz, Karwala, 2014].

Badania longitudinalne $\mathrm{z}$ udziałem dzieci $\mathrm{w}$ wieku od 9 do 15 miesięcy, dotyczące wspólnej uwagi [za: Tomasello, 2002; Białecka-Pikul, Stępień-Nycz, Karwala, 2014], koncentrujące się na pomiarach w zakresie: wspólnego zaangażowania (dziecko koordynuje uwagę zarówno wobec przedmiotu, jak i eksperymentatora), podążania za spojrzeniem oraz wskazaniem, uczenia się przez naśladowanie, posługiwania się gestami wskazującymi oraz rozumienia i produkcji języka, wykazały, iż większość badanych dzieci przejawiała wszystkie te umiejętności, poza produkcją mowy, do dwunastego miesiąca życia. Najczęstszą kolejność wyłaniania się mierzonych umiejętności oraz czas, w którym one wystąpiły, prezentuje rysunek 1 .

Gest wskazywania palcem, stanowiący osiowy objaw rozpoczynającej się rewolucji, powinien być traktowany jako istotny marker rozwojowy. Z badań Jana M. Iversona and Susan Goldin-Meadow wynika, że stosowanie tego gestu ma ścisły związek z rozwojem leksykalnym i syntaktycznym dzieci. Wyrażone początkowo gestem elementy leksykalne wcześnie pojawiają się w słowniku dziecka, natomiast kombinacje gestów i słów stanowią predykatory połączeń dwóch słów. Zdaniem badaczy wczesny gest może torować drogę do przyszłego rozwoju języka [Iverson, Goldin-Meadow, 2005], dlatego tak ważne jest jego pojawienie się w czasie rewolucji dziewiątego miesiąca. 


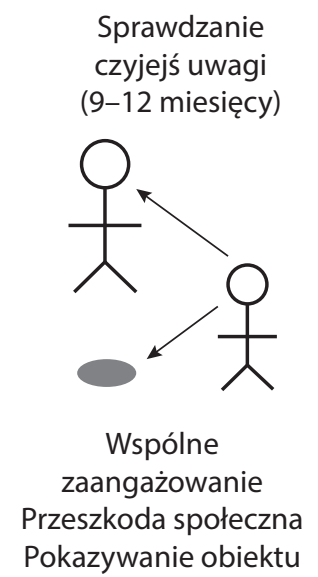

Sprawdzanie

czyjejś uwagi

miesięcy)

.
Podążanie za

czyjąś uwagą

(11-14 miesięcy)

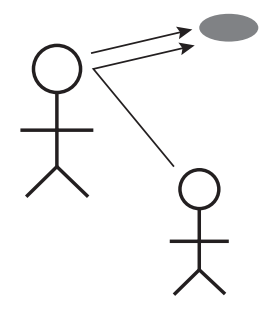

Podążanie

za wzrokiem/wskazaniem

(Odniesienie społeczne)
Kierowanie

czyjąś uwagą

(13-15 miesięcy)

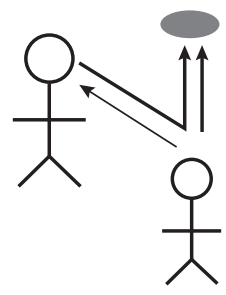

Wskazywanie nakazowe

Wskazywanie oznajmujące

(Język odniesieniowy)

Rysunek 1. Etapy rozwoju pola wspólnej uwagi

Źródło: Tomasello, 2002, s. 91.

Powyższe uwagi, wynikające z przywołanych badań, obligują do dostrzeżenia roli, jaką gesty, a szczególnie gest wskazywania palcem, pełnią w rozwoju osobniczym. W związku ze zwiększającym się odsetkiem dzieci z zaburzeniami rozwoju w badaniach przesiewowych należy poddać oglądowi nie tylko rozwój mowy, ale także rozwój niejęzykowych sprawności komunikacyjnych. Brak gestu wskazywania palcem w okresie niemowlęcym i poniemowlęcym stanowić może (między innymi) istotny marker wczesnej diagnozy autyzmu i zespołu Aspergera. Niewystąpienie tego gestu w pożądanym czasie powinno stanowić wskazanie do wywoływania go w procesie stymulacji czy też terapii psychologiczno-logopedycznej [Siudak, Bielenda-Mazur, w przygotowaniu].

\section{Literatura}

Bakeman R., Adamson L.B., 1984, Coordinating Attention to People and Objects in Mother-Infant and Peer-Infant Interaction, „Child Development”, vol. 55, no. 4, s. 1278-1289.

Bauer J., 2008, Empatia. Co potrafia neurony lustrzane, Warszawa: Wydawnictwo Naukowe PWN.

Białecka-Pikul M., Stępień-Nycz M., Karwala M., 2014, Odkrywanie kompetencji komunikacyjnych niemowlat. Skala Wczesnej Komunikacji Społecznej jako przykład narzędzia pomiarowego, „Psychologia Rozwojowa”, t. 19, nr 3, s. 51-68.

Bokus B., Shugar G.W., 2007, Psychologia jezyka dziecka - stare pytania, nowe dane, nowe hipotezy, [w:] Bokus B., Shugar G.W. (red.), Psychologia języka dziecka. Osiagnięcia, nowe perspektywy, Gdańsk: Gdańskie Wydawnictwo Psychologiczne, s. 9-32.

Butterworth G., Jarrett N., 1991, What minds have in common is space: Spatial mechanisms serving joint visual attention in infancy, „British Journal of Developmental Psychology”, vol. 9(1), s. 55-72.

Cole J., Gallagher S., McNeill D., 2002, Gesture following deafferentation: A phenomenologically informed experimental study, „Phenomenology and the Cognitive Sciences”, no. 1, s. 49-67.

Goldin-Meadow S., 1999, The role of gesture in communication and thinking, "Trends in Cognitive Sciences", vol. 3, no. 11, November, s. 419-429. 
Hellbrugge T., Lajosi F., Menara D., Schamberger R., Rautenstrauch T., 2016, Monachijska funkcjonalna diagnostyka rozwojowa. Pierwszy rok życia, Wrocław: Fundacja Promyk Słońca.

Iverson J.M., Goldin-Meadow S., 2005, Gesture paves the way for language development, „Psychological Science”, vol. 16(5), s. 367-371.

Iverson J.M., Thelen E., 1999, Hand, Mouth and Brain. The Dynamic Emergence of Speech and Gesture, „Journal of Consciousness Studies”, www.imprint-academic.com/jcs (dostęp: 20.07.2019).

Jusczyk P.W., 2007, Przyswajanie języka: dźwięki mowy i początki fonologii, [w:] B. Bokus, G.W. Shugar (red.), Psychologia języka dziecka. Osiagnięcia, nowe perspektywy, Gdańsk: Gdańskie Wydawnictwo Psychologiczne, s. 63-99.

Kaczorowska-Bray K., Milewski S., 2016, Specyfika rozwoju umiejętności komunikacyjnych dzieci z uszkodzeniem narządu wzroku, [w:] Kaczorowska-Bray K., Milewski S. (red.), Wczesna interwencja logopedyczna, Gdańsk: Wydawnictwo Harmonia Uniwersalis, s. 260-283.

Korendo M., Bielenda-Mazur E., 2016, Znaczenie kategoryzacji dla rozwoju mowy dziecka, „Annales Universitatis Paedagogicae Cracoviensis. Studia Logopaedica V", s. 176-185.

Korendo M., Bielenda-Mazur E., 2018, Neurobiologiczne reguly diagnozy i terapii neurobiologicznej, [w:] B. Szołtysek (red.), Progres neonatologii a postawa terapeutów wczesnego wspomagania rozwoju, Tarnów: Tarnowska Szkoła Wyższa, s. 26-35.

Kurcz I., 1992, Język a psychologia, Warszawa: Państwowe Wydawnictwo Naukowe.

Kurcz I., 2011, Charakterystyka kompetencji językowej - wytwarzanie i percepcja mowy, [w:] I. Kurcz, H. Okuniewska (red.), Język jako przedmiot badań psychologicznych.

Psycholingwistyka ogólna i neurolingwistyka, Warszawa: Wydawnictwo Academica, s. 66-79.

Kurcz I., Tomaszewski P., 2011, Powstawanie i ewolucja języka, [w:] I. Kurcz, H. Okuniewska (red.), Język jako przedmiot badań psychologicznych. Psycholingwistyka ogólna i neurolingwistyka, Warszawa: Wydawnictwo Academica, s. 45-65.

Przezwański R., 1959, Zjawiska dotykowe i wibracyjne. Wybrane problemy badawcze, „Zeszyty Problemowe Nauki Polskiej”, z. XVI: Kompensacja czynności narządów zmysłowych, s. 165-204.

Scaife M., Bruner J., 1975, The Capacity for Joint Visual Attention in the Infant, „Nature”, no. 253, s. $265-266$.

Siudak A., 2015, Czy rozumienie ma swoje prenatalne początki?, [w:] M. Błasiak-Tytuła, M. Korendo, A. Siudak (red.), „Nowa Logopedia”, t. 6, Kraków: Collegium Columbinum, s. 65-78.

Siudak A., 2018, Neurobiologiczne podstawy prenatalnej stymulacji narządu słuchu, [w:] M. Błasiak-Tytuła, A. Siudak (red.), Neurologopedia, t. 1, Kraków: Wydawnictwo WiR, s. $63-72$.

Siudak A., 2019, Fizjologiczne i patologiczne aspekty inwolucji zmysłów - cz. 2: Dotyk, smak i węch, [w:] B. Kazek, J. Wojciechowska (red.), Zmysly w procesie starzenia, Warszawa: Wydawnictwo Uniwersytetu Warszawskiego, s. 185-208.

Siudak A., Bielenda-Mazur E., [w przygotowaniu], Neurorozwojowy wymiar gestu wskazywania palcem - rozwój i stymulacja.

Springer S., Deutsch G., 2004, Lewy mózg, prawy mózg - z perspektywy neurobiologii poznawczej, Warszawa: Wydawnictwo Prószyński i S-ka.

Tomasello M., 2002, Kulturowe źródła ludzkiego poznawania, Warszawa: Państwowy Instytut Wydawniczy.

Załazińska A., 2006, Niewerbalna struktura dialogu w poszukiwaniu polskich wzorców narracyjnych i interakcyjnych zachowań komunikacyjnych, Kraków: Wydawnictwo Universitas.

Zyss T., 2011, Neurofizjologiczne podłoże procesu mówienia - rola somatosensorycznej kontroli zakrętów zaśrodkowych, [w:] M. Michalik (red.), „Nowa Logopedia”, t. 2, Kraków: Collegium Columbinum, s. 35-45. 
Streszczenie

W niniejszym opracowaniu przedstawione zostały zagadnienia związane z pojawieniem się w rozwoju dzieci gestu wskazywania palcem, który można uznać za kluczową zdobycz tzw. rewolucji dziewiątego miesiąca. Autorki rozpatrują znaczenie gestu w kontekście rozwoju ruchowego, poznawczo-językowego i społecznego. Podkreślając na jego neurobiologiczne podłoże, omawiają rozwój umiejętności komunikacyjnych determinujących pojawienie się gestu wskazywania palcem.

\section{Abstract}

The article presents issues related to the emergence of the pointing gesture in children's development, which can be considered the key achievement of the so-called "revolution of the ninth month". The authors discuss the significance of the gesture in the context of motor, cognitive-linguistic and social development. Making a reference to its neurobiological basis, they discuss the development of communication skills that determine the emergence of the pointing gesture. 